\title{
Editorial
}

\section{Asymptomatic COVID-19 patients: a threat to an active otolaryngologist}

\author{
Ravinder Singh Nagi ${ }^{1}$, Satinder Pal Singh ${ }^{1 *}$, Prahlad Duggal ${ }^{2}$
}

\begin{abstract}
${ }^{1}$ Department of ENT and Head Neck Surgery, Government Medical College, Amritsar, Punjab, India
${ }^{2}$ Department of ENT and Head Neck Surgery, Swift Hospital, Amritsar, Punjab, India
\end{abstract}

Received: 18 June 2020

Accepted: 01 August 2020

\author{
*Correspondence: \\ Dr. Satinder Pal Singh, \\ E-mail: satinderpalsingh44@gmail.com
}

Copyright: (C) the author(s), publisher and licensee Medip Academy. This is an open-access article distributed under the terms of the Creative Commons Attribution Non-Commercial License, which permits unrestricted non-commercial use, distribution, and reproduction in any medium, provided the original work is properly cited.

A new virus was reported for causing a spurt of pneumonia cases in Wuhan, Hubei 56 province in China in December 2019. This coronavirus, was initially named as the 2019- novel coronavirus (2019-nCoV) on 12 January 2020 by World Health Organization (WHO). WHO officially named the disease as coronavirus disease 2019 (COVID- 19) and coronavirus study group (CSG) of the International Committee proposed to name the new Coronavirus as SARS-CoV-2, both issued on 11 February 2020. ${ }^{1}$

Ever since the outbreak of coronavirus disease 2019 (COVID-19) the healthcare systems of the World have been overwhelmed by this pandemic. The recent statistics show that there are now over 5.7 million people infected and nearly 0.4 million deaths in 210 countries. Nations have implemented harsh disease control measures, including travel restrictions, expanded triage and quarantine and screening measures like temperature checkpoints. $^{2}$ A huge number of healthcare workers (HCWs) have also taken a hit during the pandemic with many countries reporting high mortality amongst HCWs. ${ }^{3-5}$

India is the second most populous country in the world with a population of more than 1.33 billion next only to China. ${ }^{6}$ There is a huge gap between public spending on healthcare in India and developed countries with India spending $1.6 \%$ of its gross domestic product (GDP) viza-viz US $8.2 \%$ and China $3.2 \%$ spending of GDP on health. ${ }^{7}$ The doctor patient ratio in India is skewed at best $1: 1456$ against the WHO recommendation of $1: 1000 .^{8,9}$ This is putting a lot of pressure on the healthcare system in India.

\section{Transmission risk and patient's screening}

The transmission of SARS-Cov 2 occurs by aerosols and the viable virus has been recovered from aerosols for up to 3 hours, porous surfaces (cardboard) for up to 24 hours, and non-porous surfaces (stainless steel, plastic) for up to 72 hours. $^{10}$ This environmental stability increases the risk of nosocomial transmission and "super spreader" events. ${ }^{11,12}$

A large percentage of COVID-19 positive patients can be asymptomatic. ${ }^{13,14}$ Also patients with mild symptoms mostly present with cough, fever, fatigue, breathing difficulty, myalgias, sore throat and chills but some recent reports also indicate that hyposmia or anosmia and dysgeusia can be under recognized symptoms. ${ }^{15-17}$

Large proportion of asymptomatic patients and common ENT complaints in mild cases pose a real threat to a practicing otolaryngologist compounded by the fact that nose, nasopharynx and throat carry high viral load and thus huge infective potential. ${ }^{18,19}$ Crowded out-patient departments coupled with shortage of personnel protective equipment (PPE), high viral load in respiratory tract and highly contagious disease, place an active otolaryngologist at great risk. It is also to be expected that instrumentation in or through those areas during outpatient procedures will entail a higher risk of transmission. ${ }^{10}$ It is pertinent to mention here that the first fatality of a physician documented globally was that of an otolaryngology physician in Wuhan on January 25, 2020 and more than 3000 health care workers including otolaryngologists have been infected in China and above 2500 in Italy. . $^{3,20}$ 


\section{Way forward in otolaryngology practice}

Given this greater risk, various Otolaryngology societies across the globe have recommended all otolaryngologic procedures, particularly those involving the upper airway, be deferred unless deemed medically necessary or until preoperative COVID-19 testing can be reliably performed. ${ }^{21}$

Elderly age and presence of co-morbidities are associated with poor outcome thereby posing risk for senior otolaryngologists. $^{22}$ Otolaryngologists should maintain high clinical suspicion for patients with mild and asymptomatic COVID-19. Routine appointments should be eliminated or delayed and telemedicine options utilized when possible. Only emergency cases should proceed in areas with high COVID-19 prevalence. Before appointment the patient screening should be implemented, including measuring temperature, acquiring epidemiologic history, and triaging according to clinical symptoms. Suspected cases should be isolated and reported immediately. ${ }^{23}$ Crowding in out-patient areas needs to be avoided at all costs. Judicious use of PPE while handing the patients..$^{23,24}$

When examinations or procedures must be performed, it is of utmost importance that otolaryngologist and any other healthcare workers in the chamber practice effective use of personal protective equipment (PPE). Meticulous cleaning of facilities and equipment should be maintained. ${ }^{25}$

\section{CONCLUSION}

Otolaryngologists play a crucial role not only in the treatment of COVID-19 patients but also are care providers to non-COVID patients. Due to the inherent nature of their work, they are at a significant risk of exposure whether working in outpatient clinics, the emergency room, or inpatient wards. There is need to preserve this scarce workforce by judicious use of PPE titrated to the level of exposure. PPE should also be used even in the absence of suspicion for COVID-19 by history alone given that patients may be asymptomatic carriers or may be contagious prior to the development of symptoms.

\section{REFERENCES}

1. Lu R, Zhao X, Li J, Niu P, Yang B, Wu H, et al. Genomic characterisation and epidemiology of 2019 novel Coronavirus: implications for virus origins and receptor binding. Lancet. 2020;395(10224):56574.

2. WHO. Coronavirus disease (COVID-2019) situation reports. 2020. Available at: https://www.who.int/ emergencies/diseases/novel-coronavirus-2019/ situationreports. Accessed on 3 March 2020.
3. Wang J, Zhou M, Liu F. Exploring the reasons for healthcare workers infected with novel coronavirus disease 2019 (COVID- 19) in China. 2019.

4. Cook T, Kursumovic E, Lennane S. Exclusive: deaths of NHS staff from covid-19 analysed. Health Service J. 2020;22:22.

5. More Than 60 Doctors in Italy Have Died in COVID-19 Pandemic - Medscape - Mar 30, 2020. Available at: https://www.medscape.com/viewarticle/927753. Accessed on 3 March 2020.

6. Population of India by Ministry of Statistics and Programme Implementation. Available at: http://statisticstimes.com/demographics/populationof-india.php. Accessed on 3 March 2020.

7. Economic Survey, 2019-20, Ministry of Finance, Available at: https://www.indiabudget.gov.in/ economicsurvey/doc/vol2chapter/echap10_vol2.pdf. Accessed on 3 March 2020.

8. The doctor-population ratio in India is $1: 1456$ against WHO recommendation. Available at: https://www.deccanherald.com/business/budget2020/no-timeline-to-remove-i-t-exemptions-financeminister-nirmala-sitharaman-805330.html. Accessed on 3 March 2020.

9. Less than one Doctor for 1,000 Population in India: Govt. Available at: http://www.hindustantimes. com/india-news/less-than-one-doctor-for-1-000population-in-india-govt-to-ls/story-olGNMk fVFFWSfZ0I23YOdM.html. Accessed on 3 March 2020.

10. Chan J, Wong E, Lam W. Practical Aspects of Otolaryngologic Clinical Services During 138 the 2019 Novel Coronavirus Epidemic: An Experience in Hong Kong. JAMA Otolaryngol Head Neck Surg. 2020.

11. van Doremalen N, Bushmaker T, Morris DH. Aerosol and surface stability of SARS-CoV-2 as compared with SARS-CoV- 1. N Engl J Med. 2020.

12. Liu Y, Eggo RM, Kucharski AJ. Secondary attack rate and superspreading events for SARS-CoV-2. Lancet. 2020;395(10227):e47.

13. $28 \%$ of 40,184 Covid positive cases in India till 30 April were asymptomatic: ICMR study. Available at: https://economictimes.indiatimes.com/news /politics-and-nation/28-of-covid-19-cases-in-indiatill-april-30-are-asymptomatic-study/printarticle/ 76106638.cms. Accessed on 3 March 2020.

14. Gao M, Yang L, Chen X, Deng Y, Yang S, Xu H, et al. A study on infectivity of asymptomatic SARSCoV-2 carriers. Res Med. 2020.

15. Guan WJ, Ni ZY, Hu Y, Liang W, Ou C, He J, et al. Clinical characteristics of coronavirus disease 2019 in China. N Engl J Med. 2020;382:1708-20.

16. Mao L, Wang M, Chen S. Neurological manifestations of hospitalized patients with COVID-19 in Wuhan, China: a retrospective case series. JAMA Neurol. 2020.

17. Hopkins C, Kumar N. Loss of Sense of Smell as a Marker of COVID-19 Infection; 2020. 
18. Zou L, Ruan F, Huang M, Huang H, Hong Z, Yu J, et al. SARS-CoV-2 viral load in upper respiratory specimens of infected patients. N Engl J Med. 2020;382(12):1177-9.

19. Rothe C, Schunk M, Sothmann P, Bretzel G, Froeschl G, Wallrauch C, et al. Transmission of 2019- nCoV infection from an asymptomatic contact in Germany. $\mathrm{N}$ Engl J Med. 2020;382(10):970-1.

20. Wang D, Hu B, Hu C, Zhu F, Liu X, Zhang J, et al. Clinical characteristics of 138 hospitalized patients with 2019 novel coronavirus-infected pneumonia in Wuhan, China. JAMA. 2020;323(11):1061-9.

21. American Academy of Otolaryngology-Head and Neck Surgery 2020. Academy Supports CMS, Offers Specific Nasal Policy. Available at: https://www.entnet.org/content/academy-supportscms-offers-specific-nasal-policy. Accessed on 2 March 2020.

22. Liang W, Guan W, Chen R, Wang W, Li J, Xu K, et al. Cancer patients in SARS-CoV-2 infection: a nationwide analysis in China. Lancet Oncol. 2020;21(3):335-7.

23. Zhao C, Viana A Jr, Wang Y, Wei HQ, Yan AH, Capasso R. Otolaryngology during COVID-19: Preventive care and precautionary measures. Am J Otolaryngol. 2020;102508.

24. Lescanne E, van der Mee-Marquet N, Juvanon JM, Abbas A, Morel N, Klein JM, et al. Best practice recommendations: ENT consultations during the COVID-19 pandemic. Eur Ann Otorhinolaryngol Head Neck Dis. 2020.

25. Panuganti BA, Pang J, Califano J, Chan JYK. Procedural precautions and personal protective equipment during head and neck instrumentation in the COVID-19 era. Head Neck. 2020;42(7):164551.

Cite this article as: Nagi RS, Singh SP, Duggal P. Asymptomatic COVID-19 patients: a threat to an active otolaryngologist. Int J Otorhinolaryngol Head Neck Surg 2020;6:1762-4. 